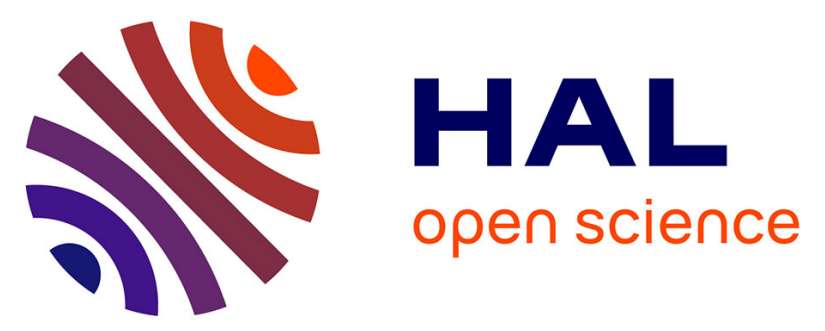

\title{
Loss of APC function in mesenchymal cells surrounding the Müllerian duct leads to myometrial defects in adult mice
}

\author{
Yongyi Wang, Yundan Jia, Patrick Franken, Ron Smits, Patricia C. Ewing, \\ John P. Lydon, Francesco J. Demayo, Curt W. Burger, J. Anton Grootegoed, \\ Riccardo Fodde, et al.
}

\section{To cite this version:}

Yongyi Wang, Yundan Jia, Patrick Franken, Ron Smits, Patricia C. Ewing, et al.. Loss of APC function in mesenchymal cells surrounding the Müllerian duct leads to myometrial defects in adult mice. Molecular and Cellular Endocrinology, 2011, 341 (1-2), pp.48. 10.1016/j.mce.2011.05.026 . hal-00719876

\section{HAL Id: hal-00719876 https://hal.science/hal-00719876}

Submitted on 22 Jul 2012

HAL is a multi-disciplinary open access archive for the deposit and dissemination of scientific research documents, whether they are published or not. The documents may come from teaching and research institutions in France or abroad, or from public or private research centers.
L'archive ouverte pluridisciplinaire $\mathbf{H A L}$, est destinée au dépôt et à la diffusion de documents scientifiques de niveau recherche, publiés ou non, émanant des établissements d'enseignement et de recherche français ou étrangers, des laboratoires publics ou privés. 


\section{Accepted Manuscript}

Loss of APC function in mesenchymal cells surrounding the Müllerian duct leads to myometrial defects in adult mice

Yongyi Wang, Yundan Jia, Patrick Franken, Ron Smits, Patricia C. Ewing, John P. Lydon, Francesco J. DeMayo, Curt W. Burger, J. Anton Grootegoed, Riccardo Fodde, Leen J. Blok

PII: S0303-7207(11)00278-4

DOI: 10.1016/j.mce.2011.05.026

Reference: MCE 7859

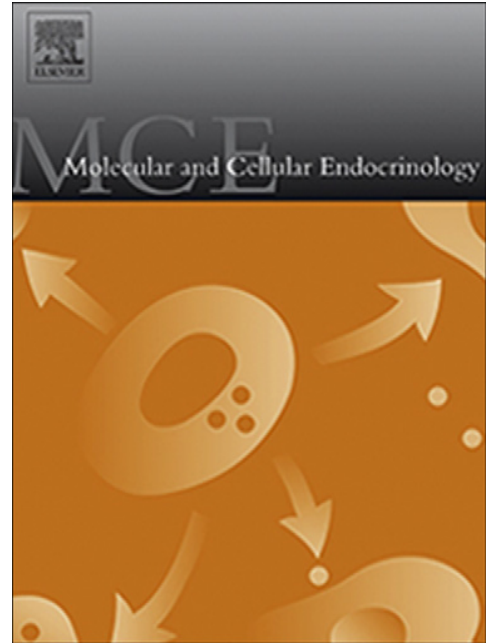

To appear in: Molecular and Cellular Endocrinology Molecular
and Cellular Endocrinology

Received Date: $\quad 16$ March 2011

Revised Date: $\quad 14$ April 2011

Accepted Date: $\quad 10$ May 2011

Please cite this article as: Wang, Y., Jia, Y., Franken, P., Smits, R., Ewing, P.C., Lydon, J.P., DeMayo, F.J., Burger, C.W., Anton Grootegoed, J., Fodde, R., Blok, L.J., Loss of APC function in mesenchymal cells surrounding the Müllerian duct leads to myometrial defects in adult mice, Molecular and Cellular Endocrinology Molecular and Cellular Endocrinology (2011), doi: 10.1016/j.mce.2011.05.026

This is a PDF file of an unedited manuscript that has been accepted for publication. As a service to our customers we are providing this early version of the manuscript. The manuscript will undergo copyediting, typesetting, and review of the resulting proof before it is published in its final form. Please note that during the production process errors may be discovered which could affect the content, and all legal disclaimers that apply to the journal pertain. 
Loss of APC function in mesenchymal cells surrounding the Müllerian duct leads to myometrial defects in adult mice

Yongyi Wang ${ }^{1}$, Yundan Jia ${ }^{1,2}$, Patrick Franken ${ }^{2}$, Ron Smits ${ }^{3}$, Patricia C. Ewing ${ }^{2}$, John P. Lydon ${ }^{4}$, Francesco J. DeMayo ${ }^{4}$, Curt W. Burger ${ }^{1}$, J. Anton Grootegoed ${ }^{5}$, Riccardo Fodde $^{2}$, and Leen J. Blok ${ }^{1}$

Department of ${ }^{1}$ Obstetrics and Gynaecology, ${ }^{2}$ Pathology, and ${ }^{3}$ Gastroenterology and Hepatology, ${ }^{5}$ Reproduction and Development, Erasmus MC, Rotterdam, The Netherlands, ${ }^{4}$ Department of Molecular and Cellular Biology, Baylor College of Medicine, Houston, USA

Running title: Loss of Apc leads to myometrial defects 


\section{Abstract}

The WNT signal transduction pathway plays a rate limiting role in early development of many different organs. To study the functional consequences of constitutive activation of the canonical WNT pathway in the developing uterus, we generated a novel mouse model where loss of the tumor suppressor gene Apc was induced. A mouse model was generated and evaluated where $A m h r 2^{\text {Cre/t+ }}$ driven loss of $A p c$ exon 15 was induced. The $A p c$ recombination was detected mainly in the myometrial layer of the adult uterus. A significant loss of muscle fibers in myometrium was apparent, though with very few muscle cells earmarked by nuclear $\beta$-catenin. The finding was confirmed in the $P g r^{\mathrm{Cre} /+} ; A p c^{15 l o x / 15 l o x}$ mouse model. Loss of APC function in mesenchymal cells surrounding the fetal Müllerian ducts results in severe defects in the myometrial layers of the uterus in adult mice, suggesting that the WNT signaling pathway plays important roles in maintaining myometrial integrity.

Key words: APC, WNT, myometrium, endometrium 


\section{Introduction}

Shortly after the onset of testis differentiation during mammalian embryonic life, the first testicular hormone to be produced is anti-Müllerian hormone (AMH), secreted by the Sertoli cells, soon followed by production of testosterone by the Leydig cells. Fetal testosterone production stabilizes the Wolffian ducts, which give rise to the epididymides and vasa deferens. AMH binds to its receptors on the mesenchymal cells surrounding the Müllerian ducts, which induces apoptosis and results in Müllerian duct regression. Because embryonic female gonads do not produce any testosterone or $\mathrm{AMH}$, Wolffian ducts will regress and Müllerian ducts are stabilized to form the upper part of the vagina, the uterus and the oviducts (Biason-Lauber, 2010). For the current investigations, we developed and analysed a novel mouse model to study the role of canonical Wnt/ $\beta$-catenin signalling in embryonic development and homeostasis of the uterus.

In canonical Wnt/ $\beta$-catenin signalling, a central role is played by the "destruction complex" consisting of three scaffolding proteins, namely AXIN1, AXIN2, and APC (adenomatous polyposis coli), two kinases, glycogen synthase kinase-3 $\beta$ (GSK3 $\beta$ ) and casein-kinase $1 \alpha(C K 1 \alpha)$, and $\beta$-catenin (CTNNB1). In the absence of extracellular Wnt ligands, formation of the destruction complex marks $\beta$-catenin by Ser-Thr phosphorylation, thus promoting its proteolytic degradation through ubiquitination. In the presence of Wnt signals however, formation of the destruction complex is inhibited and $\beta$-catenin is able to accumulate in the cytoplasm and eventually translocate to the nucleus where, in association with members of the TCF/LEF family of transcription factors, it activates transcription of a broad spectrum of downstream target genes (http://www.stanford.edu/ rnusse/pathways/targets.html). Defects in several members of the Wnt signalling cascade, i.e. loss of function 
mutations at the $A P C$ gene, result in the accumulation of intracellular and nuclear $\beta$ catenin, thus leading to constitutive deregulation of target genes (Behrens et al., 1996; Fodde et al., 1994; Molenaar et al., 1996; Morin et al., 1997; Sparks et al., 1998). During the early phases of development of the female reproductive tract, Wnt ligands such as Wnt4, Wnt5a and Wnt7a play an important role (Mericskay et al., 2004; Miller and Sassoon, 1998; Vainio et al., 1999). Wnt4 knock-out female mice develop normal Wolffian ducts but lack Müllerian ducts (Vainio et al., 1999). Wnt5a knock-out female mice are characterized by defects in the posterior outgrowth of the developing Müllerian ducts and in forming endometrial glands (Mericskay et al., 2004). Loss of Wnt7a expression on its turn, leads to incomplete demarcation between the vagina and the uterus and between the uterus and the oviduct. Furthermore, Wnt7a knock-out female mice do not form uterine glands and show myometrial aberrations (Miller and Sassoon, 1998).

More recently, two models have been developed to evaluate the consequences of conditional Wnt/ $\beta$-catenin activation in the uterus (Jeong et al., 2009; Tanwar et al., 2009). Jeong et al. (2009) investigated the effects of conditional activation of Wnt signaling in the uterus by PgrCre driven activation of $\beta$-catenin expression $\left(\mathrm{Pgrr}^{\mathrm{Cr} / /} ; \mathrm{Ctnnb}^{\mathrm{f(E \times 3)/+})}\right.$ and showed profound endometrial hyperplasia, which did not further progress to endometrial cancer (Jeong et al., 2009). Tanwar et al. (2009) employed the Amhr2 (Amh type 2 receptor) promoter to drive Cre expression $\left(A m h r 2^{\mathrm{Cre} / \mathrm{+}}\right)$ and activate $\beta$-catenin expression in mesenchymal cells surrounding the developing Müllerian ducts. This approach resulted in myometrial hyperplasia, adenomyosis, and mesenchymal tumors similar to leiomyomas and endometrial stromal sarcomas (Tanwar et al., 2009). Furthermore, hyperplasia of endometrial glands was occasionally observed suggesting that mesenchymal 
activation of $\mathrm{Wnt} / \beta$-catenin signalling plays a role in the early events which may lead to endometrial carcinogenesis.

In approximately $40 \%$ of human endometrial cancers, nuclear $\beta$-catenin staining is observed (Saegusa and Okayasu, 2001; Scholten et al., 2003), and in over $50 \%$ of these cases loss of APC expression is involved (either LOH or promoter methylation, (Moreno-Bueno et al., 2002)). In order to further clarify the role of Wnt/ $\beta$ catenin signalling, and in particular loss of Apc expression in the uterus, we bred Amhr2 ${ }^{\text {Cre/+ }}$ (Jamin et al., 2002) mice with $A p c^{15 l o x / 15 l o x}$ mice (Robanus-Maandag et al., 2010) to conditionally inactivate the endogenous $A p c$ gene from early embryonal life onwards in mesenchymal cells surrounding the Müllerian duct. 


\section{Materials and Methods}

\subsection{Animals and genotyping}

All experiments conducted with mice were approved by our local animal ethics committee (DEC permit number EUR 1076) and were in accordance to international guidelines and regulations. Amhr2-LacZ animals (Arango et al., 2008; Arango et al., 1999) and Amhr2Cre animals (Jamin et al., 2002) were obtained from Dr RR Behringer. Amhr2Cre mice were bred with Rosa26 reporter mice (Soriano, 1999) to review Cre expression, and were bred with $A p c^{1510 x}$ mice (Miclea et al., 2009; Robanus-Maandag et al., 2010) to obtain $A p c^{15 f l o x / 15 f l o x}$ mice ("flox" means that the sequence between two loxP sites has been deleted by Cre). PgrCre animals (Soyal et al., 2005) were also bred with $A p c^{15 l o x}$ mice to obtain $A p c^{15 f l o x / 15 f l o x}$ mice. All animals were maintained in a C57BI/6J background. Genotyping was performed by routine PCR, on tail and uterus DNA, using the following primers: detection of the $380 \mathrm{bp}$ Apc $^{15 l o x}$ allele: TAGGCACTGGACATAAGGGC and GTAACTGTCAAGAATCAATGG; detection of the $450 \mathrm{bp}$ Apc $^{15 \text { flox }}$ allele: AACTTCTGAGTATGATGGAGG and GTAACTGTCAAGAATCAATGG; detection of the 219 bp Cre allele: GGACATGTTCAGGGATCGCCAGGC and CGACGATGAAGCATGTTTAGCTG; detection of the 500 bp Rosa26-LacZ ${ }^{\text {lox }}$ and 250 bp Rosa26-LacZ $Z^{\text {flox }}$ allele: AAAGTCGCTCTGAGTTGTTAT, GCGAAGAGTTTGTCCTCAACC and GGAGCGGGAGAAATGGATATG. For all animals, the stage of the estrous cycle was determined by a vaginal smear just before sacrifice.

\section{2. $\beta$-Galactosidase staining}

The $\beta$-galactosidase staining was performed as described before (Dannenberg et al., 2004) with the adaptation that here Bluo-Gal (Invitrogen, Breda, The Netherlands) 
was used instead of X-gal. Fixed uteri were stained with Bluo-Gal overnight, embedded in paraffin, sectioned $(5 \mu \mathrm{m})$ and counter-stained with eosin.

\subsection{Laser microdissection}

Paraffin-embedded tissues were sectioned $(10 \mu \mathrm{m})$, adhered to uncoated microscope slides and stained with haematoxylin and eosin. Laser microdissection was performed by PALM laser microdissection (Carl Zeiss Microlmaging $\mathrm{GmbH}$, Standort Göttingen, Germany). Approximately $1 \mathrm{~mm}^{2}$ of myometrium, luminal epithelium and stromal tissue combined with glandular epithelium were collected, respectively. DNA was extracted from these tissues compartments, using a phenol-chloroform method. The genotypes of different uterine layers were assessed by PCR as described above.

\subsection{Immunohistochemistry}

Immunohistochemistry was performed essentially as described before (Klaassens et al., 2006). The antibodies employed are: mouse monoclonal anti-SMA (DAKO, Heverlee, Belgium) (1:150), rat monoclonal anti-cytokeratine 8 (CK8, 1:5000) (DSHB, Iowa, USA), rabbit polyclonal anti-ERa (Millipore, Billerica, USA) (1:2000) and rabbit monoclonal anti- $\beta$-catenin (Epitomics, Burlingame, USA) (1:800).

\subsection{Histological view and measurement}

Immunohistochemical staining for smooth muscle actin (SMA), which stains myometrium, was applied to distinguish between myometrium and endometrium. CK8 was used to specifically stain epithelial cells. Nanozoomer Digital Pathology (NDP) (Hamamatsu Photonics Deutschland GmbH, Herrsching am Ammersee, Germany) was used to scan the slides and this program also allowed for uterine area 
measurements. The number of glands was measured per square millimeter of endometrium. Of each evaluated uterus, every $2 \mathrm{~mm}$ one section was measured (7 sections per uterus), and in total thirteen control and ten experimental animals were assessed.

\subsection{Statistical methods}

Analyses were performed using Graphpad Prism 5 (GraphPad Software, Inc., San

Diego, CA). Unpaired, two-tailed t-test was used to analyze the differences between groups. $\mathrm{P}$ values lower than 0.05 were considered statistically significant. 


\section{Results}

\subsection{The Amhr2 promoter is mainly active in the myometrium}

First we established the pattern of expression driven by the promoter of Amhr2 in the uterus by employing previously developed Amhr2-LacZ reporter mice (Arango et al., 2008). As shown in Figure 1A, LacZ expression was limited to the myometrial layer of the uterus. This result was confirmed by breeding Amhr2 ${ }^{\mathrm{Cre} /+}$ transgenic animals with the Rosa26 reporter mice (R26R) carrying a loxP-STOP-loxP-lacZ reporter (Soriano, 1999). In the presence of active Cre, somatic deletion of the STOP cassette is achieved, thus leading to $\beta$-galatosidase expression from the $L a c Z$ gene. Figure $1 \mathrm{~B}$ shows $\beta$-galatosidase staining of both myometrial layers (inner circular and outer longitudinal muscles) in compound $A m h r 2^{\text {Cre/ }} ;$ R26R animals. Notably, staining was not continuous throughout the myometrium as exemplified by patchy $\beta$-galactosidase expression within the outer myometrial layer, which is in accordance with a previous publication by Deutscher and Yao (Deutscher and Hung-Chang Yao, 2007). Staining for $\beta$-galactosidase also indicated that the Amhr2 promoter is not active in stromal and epithelial cells of the endometrium.

Next, Amhr2Cre animals were bred with $A p c^{1510 \times / 15 l o x}$ animals, a model developed by our laboratory (Robanus-Maandag et al., 2010) to conditionally inactivate Apc function by removing exon 15 of the endogenous gene. Deletion of both $A p c$ alleles results in the constitutive activation of $W n t / \beta$-catenin signaling. To substantiate that Cre expression in the compound $A m h r 2^{\mathrm{Cre} /+} ; A p c^{1510 x / 15 l o x}$ animals was limited to the myometrial layer, and to verify that recombination of the Apc gene was indeed taking effect, laser capture microdissection (LCM) of different layers of the uterus was performed. As illustrated in Figure 1C and 1D, only a small percentage of cells from the stromal/glandular region showed Apc exon 15 deletion, 
whereas no somatic recombination was detected in the luminal epithelial region. In contrast, $A p c$ deletion was evident in cells from in the myometrium.

Somatic Apc deletion is predicted to result in the constitutive activation of the canonical Wnt pathway and, possibly, in the nuclear accumulation of $\beta$-catenin (Gaspar and Fodde, 2004; Robanus-Maandag et al., 2010). However, IHC analysis of $\beta$-catenin expression in the uterus of $A m h r 2^{\mathrm{Cre} /+} ; A p c^{15 l o x / 15 l o x}$ animals revealed that the majority of myometrial cells are marked by cytoplasmatic $\beta$-catenin staining with only few cells showing nuclear staining (Fig. 1E). This result is in agreement with previous studies from our and other laboratories showing that loss of Apc function is necessary but often insufficient for nuclear $\beta$-catenin accumulation (Fodde and Brabletz, 2007; Fodde and Tomlinson, 2010).

\subsection{Loss of APC function results in myometrial defects}

Histological assessment of uteri from adult compound $A m h r 2^{\mathrm{Cre} /+} ; A p c^{15 l o x / 15 l o x}$ mice revealed severe defects in the myometrium (an overview of the analyzed mice is presented in Table 1). To investigate the nature of these defects in more detail, smooth muscle actin (SMA) IHC staining was employed to specifically mark the myometrium. As shown in Figure 2, in contrast to control animals (Fig. 2A), all Amhr2 $2^{\mathrm{Cre} /+} ; A p c^{15 l o x / 15 l o x}$ animals showed regions within the myometrium where the muscle layer appeared disorganized or even discontinuous (Fig. 2B). Out of the 19 $A m h r 2^{\text {cre/+}} ; A p c^{15 l o x / 15 l o x}$ mice here examined, 16 showed tissue architectural changes of the myometrium without interruption of the myometrium layer, as exemplified in Figure 2B (top panel). In the other 3 of 19 animals the same architectural changes in the myometrium appeared in association with a discontinuous myometrium layer, as exemplified in panels 2 and 3 of Figure 2B. Pregnancies in $A m h r 2^{\mathrm{Cre} /+} ; A p c^{15 l o x / 15 l o x}$ 
animals only resulted in life born puppies in 2/4 cases. On the other 2/4 cases the mother died during delivery. In order to investigate these delivery problems futher, we tried to obtain permission with our local animal ethics committee, but it was not allowed.

To obtain additional evidence that loss of Apc function in myometrial cells of the uterus indeed results in muscular defects in the adult uterus, $A p c^{15 \text { lox/15lox }}$ animals were bred with PgrCre animals. In these animals nuclear $\beta$-catenin staining was readily detected in the myometrium and in epithelial cells of the endometrium (Fig. 3A). Furthermore, marked myometrial defects were detected in the majority of investigated animals (7/10) (Fig. 3B). Interestingly, omissions in the myometrial layer were invaded by stromal and glandular cells from the endometrium reminiscent for a human disorder described as endometriosis interna or adenomyosis (Bergeron et al., 2006).

In order to assess the underlying basis for the effects of the induced Apc mutation, embryonal mice were sacrified and the Müllerian ducts were stained for apoptosis (caspase-3). Time of sacrifice (E12) was chosen based on our own data in Amhr2 ${ }^{\mathrm{Cre} /+}$; R26R-LacZ animals showing clear Cre activity around that day. No differences, however, were detected between controls and $A m h r 2^{\mathrm{Cre} /+} ; A p c^{15 l o x / 15 l o x}$ littermates (data not shown).

\subsection{Endometrial defects in $A m h r 2^{\text {cre/+}} ; A p c^{15 l o x / 15 l o x}$ mice}

Although recombination of $A p c^{15 l o x}$ alleles in the endometrium could hardly be detected in the $A m h r 2^{\mathrm{Cre} /+} ; A p c^{15 l o x / 15 l o x}$ animals, phenotypic expression of gene deletion was apparent from observed differences between targeted and control animals, such as a smaller endometrial area and less endometrial glands. To quantify 
these differences, anti-SMA was used to stain myometrium, and anti-CK8 was used to stain endometrial glands (Fig. 4A and 4B). As indicated in Materials and Methods several areas were measured and gland numbers counted. Despite the myometrial defects described above, no significant differences could be detected in the myometrial area of $A m h r 2^{\mathrm{Cre} /+} ; A p c^{15 l o x / 15 l o x}$ animals when compared with control animals (Fig. 4C). However, significant differences were observed for the number of glands per $\mathrm{mm}^{2}$ (Fig. 4D, $\mathrm{p}=0.0001$ ) and the area of the endometrium (Fig. 4E, $\mathrm{p}=$ 0.0002): $A m h r 2^{\mathrm{Cre} /+} ; A p c^{15 l o x / 15 l o x}$ mice show fewer glands and a reduction of the endometrial area. 


\section{Discussion}

The functional role of canonical Wnt/ $\beta$-catenin signalling in uterine development and homeostasis is to date largely unclear. Recently, Jeong et al. (2009) investigated the effects of conditional activation of Wnt signaling in the uterus by PgrCre driven expression of oncogenic $\beta$-catenin $\left(\mathrm{Pgr}^{\mathrm{Cre} /+} ; \mathrm{Ctnnb}^{\mathrm{f(E \times 3)/+}}\right)(\mathrm{Jeong}$ et al., 2009). The progesterone receptor, however, is widely expressed throughout the uterus from week two after birth onwards, and accordingly a broad spectrum of defects was observed: the $P G R^{\mathrm{Cre} /+} ;$ Ctnnb $1^{\mathrm{f(E \times 3)/+}}$ animals showed reduced offspring numbers resulting from a diminished decidual reaction, decreased uterine weight, increased ERa expression in the endometrium, enlarged endometrial glands, endometrial hyperplasia, and increased endometrial proliferation.

In the present study the aim was to investigate the consequences of $\mathrm{Wnt} / \mathrm{\beta}$ catenin activation by Apc deletion in embryonal life for specific adult uterine tissues. In particular, the Amhr2 promoter was employed to drive Cre expression to induce loss of $A p c$ function $\left(A m h r 2^{\text {Crel- }} ; A p c^{1510 x / 1510 x}\right)$ in the myometrium but not in the endometrium. The main difference between the current approach and studies by others on the role of $\mathrm{Wnt} / \beta$-catenin signaling in the uterus (Arango et al., 2005) (Deutscher and Hung-Chang Yao, 2007; Jeong et al., 2009; Tanwar et al., 2009) is that here conditional knock-down of $A p c$ is used (others use conditional inactivation or activation of $\beta$-catenin). The role of APC of course is different from the role of $\beta$ catenin: APC is involved in cell adhesion, migration, apoptosis and chromosomal segregation (Fodde, 2003). This is true, however, the main tumor-suppressing function of APC instigates from its role in the $W n t / \beta$-catenin signalling pathway.

Previous studies with the Amhr2-LacZ reporter mouse model showed that this promoter is active for a brief period from embryonic day 12.5 to 15.5 in mesenchymal 
cells surrounding the Müllerian ducts (Arango et al., 2008; Jamin et al., 2002; Klattig et al., 2007). Notably, in a related reporter model, Amhr2Cre-driven recombination of a Rosa26 reporter (R26R) resulted in $\beta$-galactosidase staining of myometrial cells but not in endometrial stromal cells (Arango et al., 2008; Deutscher and Hung-Chang Yao, 2007). This observation was confirmed in the current study also by assessing somatic recombination of the Apc15/ox allele in laser-capture microdissected areas of the uterus of $A m h r 2^{\mathrm{Cre} /+} ; A p c^{1510 \times / 15 l o x}$ mice (Fig. 1).

A more detailed approach to the determination of Cre-mediate recombination efficiency is represented by $\beta$-catenin immunohistochemical staining. Nuclear $\beta$ catenin accumulation is often regarded as a hallmark of Wnt/ $\beta$-catenin signalling activation as the result of loss of Apc function. However, $\beta$-catenin IHC analysis of the myometrium of $A m h r 2^{\mathrm{Cre} /+} ; A p c^{15 l o x / 15 l o x}$ animals revealed a majority of cells with cytoplasmatic staining and only very few, sporadic cells with clear-cut nuclear staining. This is consistent with the observed patchy $\beta$-galactosidase staining (Fig. 1B). Furthermore, Miclea et al. (2009) and Robanus-Maandag et al. (2010) showed increased intracellular $\beta$-catenin staining upon somatic Apc deletion with only a minority of cells featuring nuclear accumulation (Miclea et al., 2009; RobanusMaandag et al., 2010). Interestingly these authors did show a clear phenotype resulting from the intestinal Cre-mediated deletion of Apc: tumors in the large intestine (Robanus-Maandag et al., 2010). Accordingly, other reports have shown that loss of APC function is necessary but not always sufficient for nuclear $\beta$-catenin accumulation (Fodde and Brabletz, 2007; Fodde and Tomlinson, 2010). In contrast to this, $\mathrm{Pgr}^{\mathrm{Cre} /+} ; A p c^{15 \mathrm{lox} / 15 \mathrm{lox}}$ animals did show nuclear $\beta$-catenin staining indicating that recombination of $\mathrm{Apc}$ can indeed result in nuclear $\beta$-catenin staining. There is however a considerable difference between the two models: Amhr2Cre is activated 
only from embryonal day 12.5 to 15.5 while PgrCre becomes active and stays active from approximately postnatal day 10 onwards. It is possible that the majority of mesenchymal cells surrounding the embryonal Mullerian duct (where loss of Apc function is established) selectively undergo apoptosis, while more mature myometrial cells in which Apc is knocked down, do not. In fact apoptosis as a result of activation of Wnt/ $\beta$-catenin signalling has previously been shown for $\mathrm{NIH}-3 \mathrm{~T} 3$ fibroblasts (Kim et al., 2000). The latter would also be in agreement with the observed loss of myometrial muscle tissue in some of the animals upon Apc somatic deletion, described herein (Fig. 2 and 3). Reviewing Müllerian duct sections from embryonal day $14 A m h r 2^{\mathrm{Cre} /+} ; A p c^{15 \text { lox/15lox }}$ animals, however, failed to show increased apoptosis as measured by caspase 3 staining (data not shown). Evaluation of the uterus of $\mathrm{Pgr}^{\mathrm{Cre} /+} ; A p c^{15 \mathrm{lox} / 15 \mathrm{lox}}$ animals indicated that it can not be excluded that loss of myometrial muscle fibers develops gradually over a prolonged period of time, or alternatively from pubertal life onwards.

The most prevalent phenotype observed among $A m h r 2^{\mathrm{Cre} /+} ; A p c^{15 l o x / 15 l o x}$ mice is undoubtedly represented by the loss and disorganisation of myometrial muscle fibres resulting in a defective myometrium. Myometrial defects were also observed by others by employing comparable models to either induce or inhibit Wnt/ $\beta$-catenin signalling in utero. Arango et al. (2005) used the Amhr2Cre model to induce $\beta$ catenin depletion and observed profound myometrial defects (Arango et al., 2005). In that study, $\beta$-catenin depletion in mesenchymal cells surrounding the Müllerian ducts resulted in the appearance of adipocytes replacing myometrial cells. Miller and Sassoon (1997) found that in Wnt7a defective animals, among many other disorders, the myometrial layer became largely disorganized (Miller and Sassoon, 1998). Tanwar et al. (2009) used a model which mimics more closely our approach in that 
Amhr2Cre was employed to express an oncogenic variant of $\beta$-catenin thus inducing constitutive Wnt activation in the uterus (Tanwar et al., 2009). However, in that study the affected animals developed muscular hyperplasia already at 6 weeks of age, which is substantially different from the current findings in $\mathrm{Amhr} 2^{\mathrm{Cre} /+} ; A p c^{1510 x / 1510 x}$ mice. Tanwar et al. (2009) also observed mesenchymal tumors with characteristics of human leiomyomas and endometrial stromal sarcomas (Tanwar et al., 2009). To investigate whether similar neoplastic lesion could be observed in the $A m h r 2^{\mathrm{Cre} /+} ; A p c^{1510 \times / 15 l o x}$ mice, we carefully reviewed all our mice but did not observe any leiomyomas. However, we did observe, in a single mouse, a region reminiscent of an endometrial stromal sarcoma-like lesion (Supplementary Fig. 1). This region was subsequently stained for SMA, ERa and $\beta$-catenin. It was observed that ERa and $\beta$-catenin expression were both enhanced in this region, which was in agreement with the observations done by Tanwar et al. (Tanwar et al., 2009).

Recently, we have extended our analysis on the consequences of loss of Apc function in the uterus by employing PgrCre mice (Fig. 3). Myometrial breakdown in $\mathrm{Pgr}^{\mathrm{Cre} /+} ; A p c^{1510 x / 15 l_{0 x}}$ animals was to some extent comparable to myometrial defects in $A m h r 2^{\mathrm{Cre} /+} ; A p c^{1510 x / 1510 x}$ animals. However, $\mathrm{Pgr}^{\mathrm{Cre} /+} ; A p c^{1510 \times / 15 l o x}$ animals were also characterized by areas in the myometrium nearing some similarity to human adenomyosis, a condition characterized by the presence of endometrial tissue within the myometrium. Accordingly, Tanwar et al. (2009) occasionally also observed glands and stroma in the muscle of $A m h r 2^{\mathrm{Cre} /+} ; \operatorname{Ctnnb} 1^{\mathrm{f(E \times 3)/+}}$ animals (Tanwar et al., 2009). Because in the $A m h r 2^{\mathrm{Cre} /+} ; A p c^{15 \text { lox/15lox }}$ model the integrity of the myometrium is mainly affected, this seems to indicate that the presence of endometrial tissue into the myometrial layer in the Wnt-activated mice may be the result of a passive process rather than signifying active invasion. Recent investigations by Mehasseb et 
al (2010) also indicate that invasion of stromal cells from adenomyosis is augmented by the presence of myocytes from affected uteri (Mehasseb et al., 2010).

In conclusion, we report that in vivo inactivation of the endogenous mouse $A p c$ gene in mesenchymal cells surrounding the Müllerian ducts results in significant myometrial defects in adult mice. Overall, these results further consolidate the notion that $\mathrm{Wnt} / \beta$-catenin signalling is important for uterine development and homeostasis. 


\section{ACKNOWLEDGMENTS}

We would like to thank dr. R.R. Behringer for providing us with the Amhr2Cre mouse model and dr. A.P.N Themmen and A.G. McLuskey-Dankbar, BSc, for the AMHR2LacZ staining. We would like to acknowledge technical support from Liesbeth Kuhne, BSc. 


\section{Legends}

Figure $1 \mathrm{Amhr} 2$ promoter activity and $A p c$ recombination in different regions of the uterus. A: Amhr2-LacZ mice were stained for $\beta$-galactosidase activity with BluoGal. B: Amhr2 $2^{\mathrm{Cre} / \mathrm{t}} ; \mathrm{R} 26 \mathrm{R}$ animals were stained for $\beta$-galactosidase activity. C: Indicated different layers of the uterus that were isolated by microdissection for DNA isolation. (0), before dissection; (1), glands and stroma; (2), luminal epithelium; (3), myometrium. D: Representative gel-image from a PCR reaction to determine recombination of $A p c$ using DNA isolated from an $A m h r 2^{\mathrm{Cre} /+} ; A p c^{1510 x / 15 l o x}$ mouse: (1), stroma and glands; (2) luminal epithelium; (3) myometrium. $A p c^{15 l o x}$ represents the non-recombined lox allele; $A p c^{\text {flox }}$ indicates recombination of $A p c$; Actin was used as a control for PCR. L/L represents DNA displaying both non-recombined $A p c^{15 L o x}$ alleles; F/L represents DNA displaying one non-recombined and one-recombined Apc allele. Primers used for the PCR are described in Materials and Methods. E: $\beta$ catenin staining of a representative $A m h r 2^{\mathrm{Cre} /+} ; A p c^{15 l o x / 15 l o x}$ mouse. The arrows indicate myometrial cells which show nuclear $\beta$-catenin staining. Luminal and glandular epithelial cells only show cytoplasmic and membrane $\beta$-catenin staining. Control animals never showed nuclear $\beta$-catenin staining.

Figure $2 A m h r 2^{\mathrm{Cre} /+} ; A p c^{15 l o x / 15 l o x}$ mice show myometrial defects. The uterine muscle was stained with an antibody against Smooth Muscle Actin (SMA) A: three control animals at different stages of the estrous cycle: from top to bottom: proestrus, estrus and diestrus. The staining shows a cellular myometrium with closely-packed muscle fibers. B: Three $A m h r 2^{\mathrm{Cre} /+} ; A p c^{15 l o x / 15 l o x}$ mice, matched for age and stage of the cycle to the controls. The top figure shows an affected uterus where the outer part of the myometrium contains tightly packed fibers, but the inner part shows more 
dispersed and thinner fibers. The middle and bottom figures show a complete transsection of the uterus where the muscle wall is focally incomplete.

Figure $3 \mathrm{Pgr}^{\mathrm{Cre} /+} ; A p c^{15 l o x / 15 l o x}$ mice also display myometrial defects. $\beta$-catenin (A) and SMA (B) staining of a representative $\mathrm{Pgr}^{\mathrm{Cre} /{ }} ; A p c^{15 l o x / 15 l o x}$ mouse. Details on the right indicate presence of glandular and stromal cells in the muscle layer. Gland (red arrow), stroma (black arrow) and myometrium (green arrow).

Figure 4 Quantification of endometrial and myometrial defects in $A m h r 2^{\mathrm{Cre} /+} ; A p c^{15 l o x / 15 l o x}$ mice. A: a cross section from a control uterus stained for smooth muscle actin and counterstained with hematoxylin. Indicated regions provide information on the area of the myometrium and endometrium. B: consecutive section was stained for cytokeratine 8 in order to measure the number of endometrial glands. C: calculation of the myometrial area in control and affected animals $\mathbf{D}$ : measurement of the number of glands per area of stroma in control and affected animals. E: calculation of the endometrial area in control and affected animals. The panels $\mathbf{C}-\mathbf{E}$ were derived from 13 controls and $10 \mathrm{Amhr} 2^{\mathrm{Cre} /+} ; A p c^{15 l o x / 15 l o x}$ mice $(7$ sections per animal). Con $=$ control animals; Cre-lox $=A m h r 2^{\text {Cre/t}} ; A p c^{15 l o x / 15 l o x}$ animals. Data are presented as: Mean (line), $25^{\text {th }}$ and $75^{\text {th }}$ percentiles (box), and $5^{\text {th }}$ and $95^{\text {th }}$ percentiles (whiskers).

Supplementary Figure 1 Endometrial stromal sarcoma-like lesion observed in one $A m h r 2^{\mathrm{Cre} /+} ; A p c^{15 l o x / 15 l o x}$ mouse. A and B: Hematoxylin/eosine staining of the affected uterus showing the lesion (red circle indicates the aberrant region); the 
square indicates the magnified region depicted in figure b B. Consecutive sections were stained for SMA (C), Estrogen Receptor alpha (D) and $\beta$-catenin (E). 


\section{References}

Arango, N.A., Kobayashi, A., Wang, Y., Jamin, S.P., Lee, H.H., Orvis, G.D., Behringer, R.R., 2008. A mesenchymal perspective of Mullerian duct differentiation and regression in Amhr2-lacZ mice. Mol Reprod Dev 75, 11541162.

Arango, N.A., Lovell-Badge, R., Behringer, R.R., 1999. Targeted mutagenesis of the endogenous mouse Mis gene promoter: in vivo definition of genetic pathways of vertebrate sexual development. Cell 99, 409-419.

Arango, N.A., Szotek, P.P., Manganaro, T.F., Oliva, E., Donahoe, P.K., Teixeira, J., 2005. Conditional deletion of beta-catenin in the mesenchyme of the developing mouse uterus results in a switch to adipogenesis in the myometrium. Dev Biol 288, 276-283.

Behrens, J., von Kries, J.P., Kuhl, M., Bruhn, L., Wedlich, D., Grosschedl, R., Birchmeier, W., 1996. Functional interaction of beta-catenin with the transcription factor LEF-1. Nature 382, 638-642.

Bergeron, C., Amant, F., Ferenczy, A., 2006. Pathology and physiopathology of adenomyosis. Best Pract Res Clin Obstet Gynaecol 20, 511-521.

Biason-Lauber, A., 2010. Control of sex development. Best Pract Res Clin Endocrinol Metab 24, 163-186.

Dannenberg, J.H., Schuijff, L., Dekker, M., van der Valk, M., te Riele, H., 2004. Tissue-specific tumor suppressor activity of retinoblastoma gene homologs p107 and p130. Genes Dev 18, 2952-2962.

Deutscher, E., Hung-Chang Yao, H., 2007. Essential roles of mesenchyme-derived beta-catenin in mouse Mullerian duct morphogenesis. Dev Biol 307, 227-236.

Fodde, R., 2003. The multiple functions of tumour suppressors: it's all in APC. Nat Cell Biol 5, 190-192.

Fodde, R., Brabletz, T., 2007. Wnt/beta-catenin signaling in cancer stemness and malignant behavior. Curr Opin Cell Biol 19, 150-158.

Fodde, R., Edelmann, W., Yang, K., van Leeuwen, C., Carlson, C., Renault, B., Breukel, C., Alt, E., Lipkin, M., Khan, P.M., et al., 1994. A targeted chaintermination mutation in the mouse Apc gene results in multiple intestinal tumors. Proc Natl Acad Sci U S A 91, 8969-8973.

Fodde, R., Tomlinson, I., 2010. Nuclear beta-catenin expression and Wnt signalling: in defence of the dogma. J Pathol 221, 239-241.

Gaspar, C., Fodde, R., 2004. APC dosage effects in tumorigenesis and stem cell differentiation. Int J Dev Biol 48, 377-386.

Jamin, S.P., Arango, N.A., Mishina, Y., Hanks, M.C., Behringer, R.R., 2002. Requirement of Bmpr1a for Mullerian duct regression during male sexual development. Nat Genet 32, 408-410.

Jeong, J.W., Lee, H.S., Franco, H.L., Broaddus, R.R., Taketo, M.M., Tsai, S.Y., Lydon, J.P., DeMayo, F.J., 2009. beta-catenin mediates glandular formation and dysregulation of beta-catenin induces hyperplasia formation in the murine uterus. Oncogene 28, 31-40.

Kim, K., Pang, K.M., Evans, M., Hay, E.D., 2000. Overexpression of beta-catenin induces apoptosis independent of its transactivation function with LEF-1 or the involvement of major G1 cell cycle regulators. Mol Biol Cell 11, 3509-3523.

Klaassens, A.H., van Wijk, F.H., Hanifi-Moghaddam, P., Sijmons, B., Ewing, P.C., Ten Kate-Booij, M.J., Kooi, G.S., Kloosterboer, H.J., Blok, L.J., Burger, C.W., 
2006. Histological and immunohistochemical evaluation of postmenopausal endometrium after 3 weeks of treatment with tibolone, estrogen only, or estrogen plus progestagen. Fertil Steril 86, 352-361.

Klattig, J., Sierig, R., Kruspe, D., Besenbeck, B., Englert, C., 2007. Wilms' tumor protein Wt1 is an activator of the anti-Mullerian hormone receptor gene Amhr2. Mol Cell Biol 27, 4355-4364.

Mehasseb, M.K., Bell, S.C., Pringle, J.H., Habiba, M.A., 2010. Uterine adenomyosis is associated with ultrastructural features of altered contractility in the inner myometrium. Fertil Steril 93, 2130-2136.

Mericskay, M., Kitajewski, J., Sassoon, D., 2004. Wnt5a is required for proper epithelial-mesenchymal interactions in the uterus. Development 131,20612072.

Miclea, R.L., Karperien, M., Bosch, C.A., van der Horst, G., van der Valk, M.A., Kobayashi, T., Kronenberg, H.M., Rawadi, G., Akcakaya, P., Lowik, C.W., Fodde, R., Wit, J.M., Robanus-Maandag, E.C., 2009. Adenomatous polyposis coli-mediated control of beta-catenin is essential for both chondrogenic and osteogenic differentiation of skeletal precursors. BMC Dev Biol 9, 26.

Miller, C., Sassoon, D.A., 1998. Wnt-7a maintains appropriate uterine patterning during the development of the mouse female reproductive tract. Development $125,3201-3211$.

Molenaar, M., van de Wetering, M., Oosterwegel, M., Peterson-Maduro, J., Godsave, S., Korinek, V., Roose, J., Destree, O., Clevers, H., 1996. XTcf-3 transcription factor mediates beta-catenin-induced axis formation in Xenopus embryos. Cell 86, 391-399.

Moreno-Bueno, G., Hardisson, D., Sanchez, C., Sarrio, D., Cassia, R., Garcia-Rostan, G., Prat, J., Guo, M., Herman, J.G., Matias-Guiu, X., Esteller, M., Palacios, J., 2002. Abnormalities of the APC/beta-catenin pathway in endometrial cancer. Oncogene 21, 7981-7990.

Morin, P.J., Sparks, A.B., Korinek, V., Barker, N., Clevers, H., Vogelstein, B., Kinzler, K.W., 1997. Activation of beta-catenin-Tcf signaling in colon cancer by mutations in beta-catenin or APC. Science 275, 1787-1790.

Robanus-Maandag, E.C., Koelink, P.J., Breukel, C., Salvatori, D.C., JagmohanChangur, S.C., Bosch, C.A., Verspaget, H.W., Devilee, P., Fodde, R., Smits, R., 2010. A new conditional Apc-mutant mouse model for colorectal cancer. Carcinogenesis 31, 946-952.

Saegusa, M., Okayasu, I., 2001. Frequent nuclear beta-catenin accumulation and associated mutations in endometrioid-type endometrial and ovarian carcinomas with squamous differentiation. J Pathol 194, 59-67.

Scholten, A.N., Creutzberg, C.L., van den Broek, L.J., Noordijk, E.M., Smit, V.T., 2003. Nuclear beta-catenin is a molecular feature of type I endometrial carcinoma. J Pathol 201, 460-465.

Soriano, P., 1999. Generalized lacZ expression with the ROSA26 Cre reporter strain. Nat Genet 21, 70-71.

Soyal, S.M., Mukherjee, A., Lee, K.Y., Li, J., Li, H., DeMayo, F.J., Lydon, J.P., 2005. Cre-mediated recombination in cell lineages that express the progesterone receptor. Genesis 41, 58-66.

Sparks, A.B., Morin, P.J., Vogelstein, B., Kinzler, K.W., 1998. Mutational analysis of the APC/beta-catenin/Tcf pathway in colorectal cancer. Cancer Res 58, 11301134.

Tanwar, P.S., Lee, H.J., Zhang, L., Zukerberg, L.R., Taketo, M.M., Rueda, B.R., 
Teixeira, J.M., 2009. Constitutive activation of Beta-catenin in uterine stroma and smooth muscle leads to the development of mesenchymal tumors in mice. Biol Reprod 81, 545-552.

Vainio, S., Heikkila, M., Kispert, A., Chin, N., McMahon, A.P., 1999. Female development in mammals is regulated by Wnt-4 signalling. Nature 397, 405409. 


\section{Figure 1}

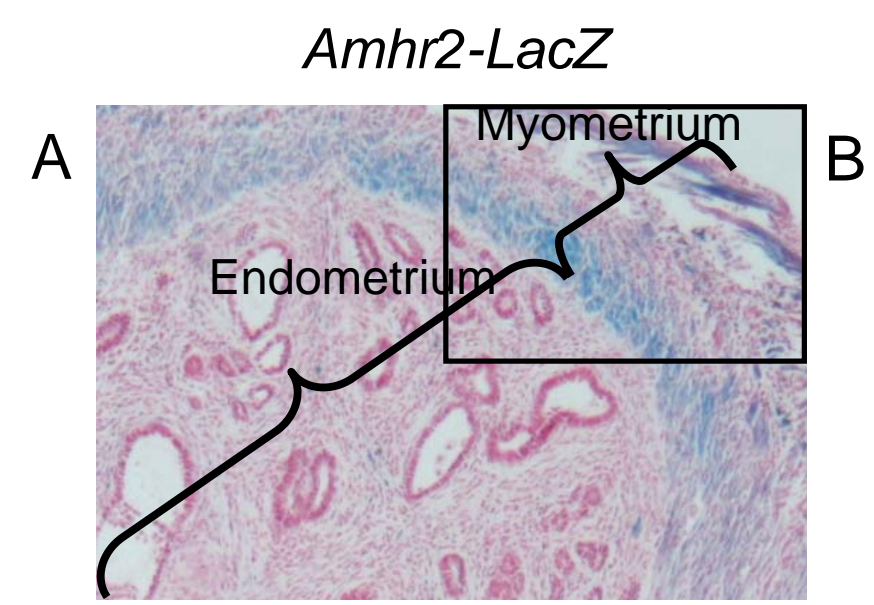

Amhr2 ${ }^{\mathrm{Cre} /+\cdot ; R o s a 26-\text { LacZ }^{\mathrm{lox}}}$

B

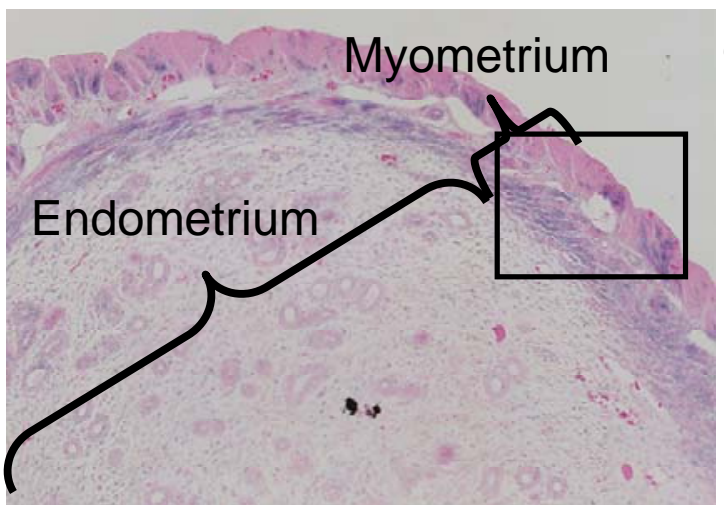

C
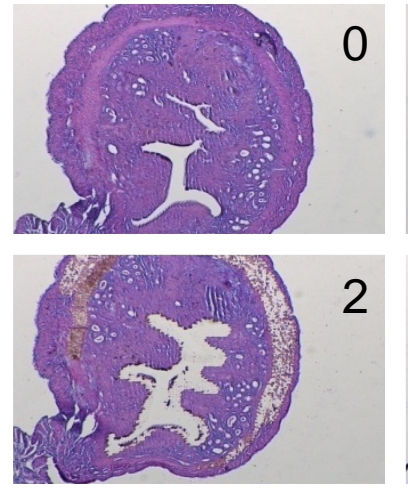

2

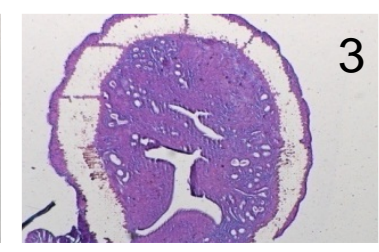

Amhr2 ${ }^{\mathrm{Cre} /+} ; A p c^{15 l o x / 15 l o x}$
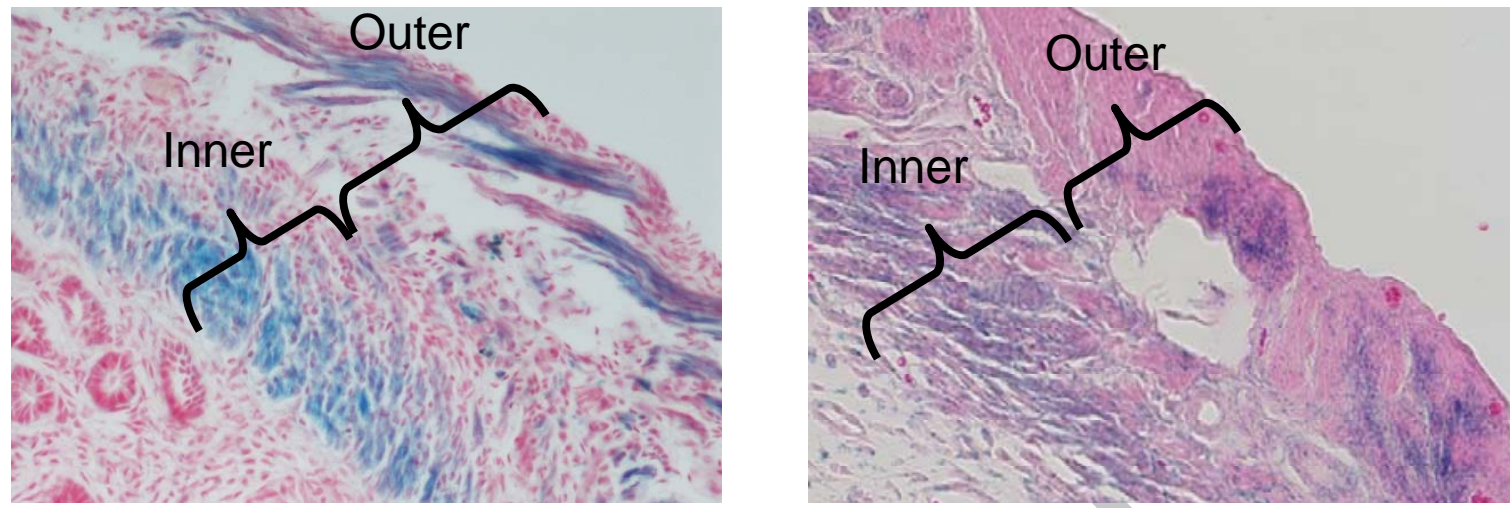

(

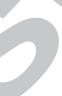

\section{Amhr2 $2^{\mathrm{Cre} /+} ; A p c^{15 l o x / 15 l o x}$}

$\begin{array}{llllll}D & 1 & 2 & 3 & \text { L/L } & \text { F/L }\end{array}$

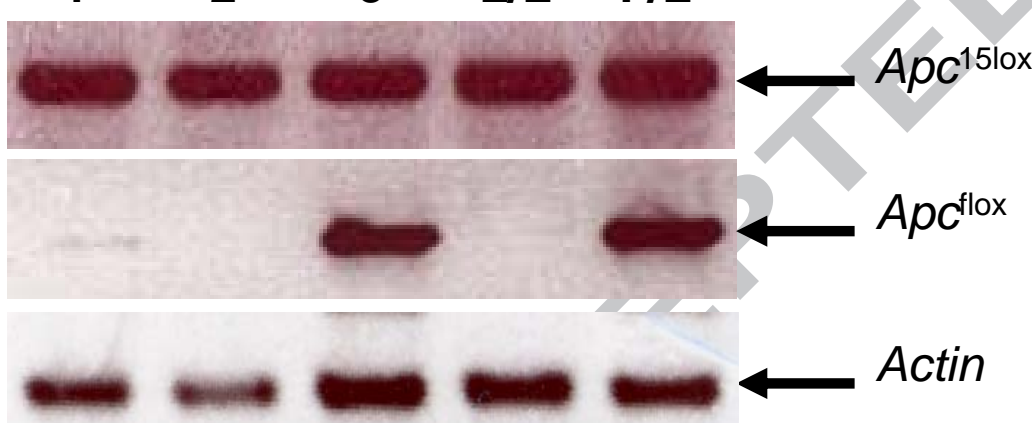

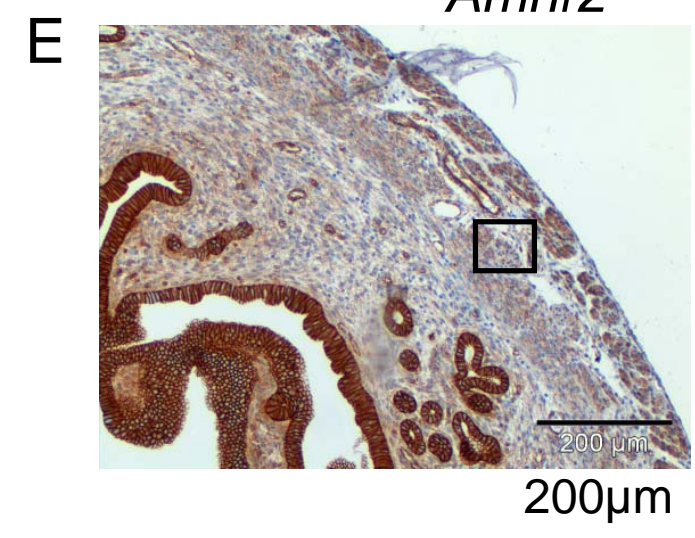

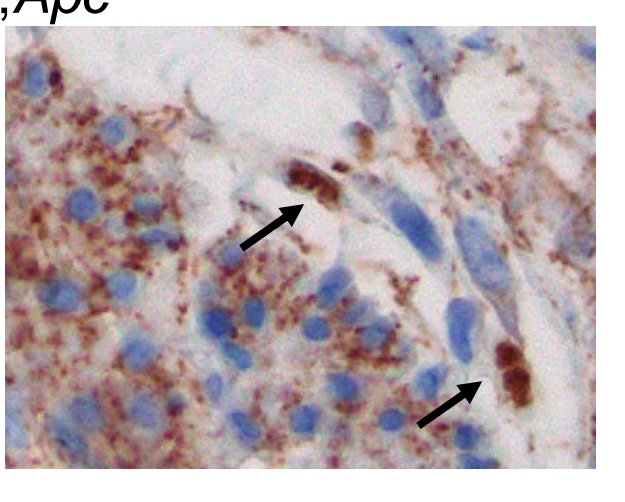




\section{Figure 2}
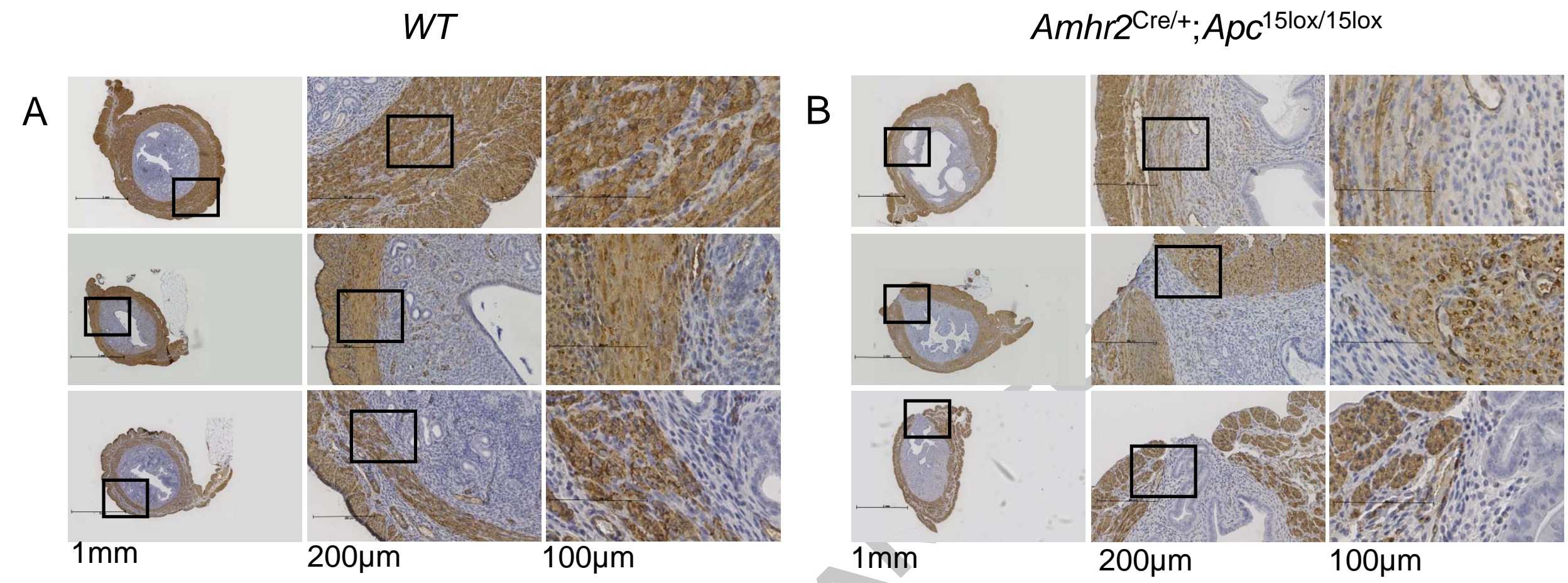

$1 \mathrm{~mm}$
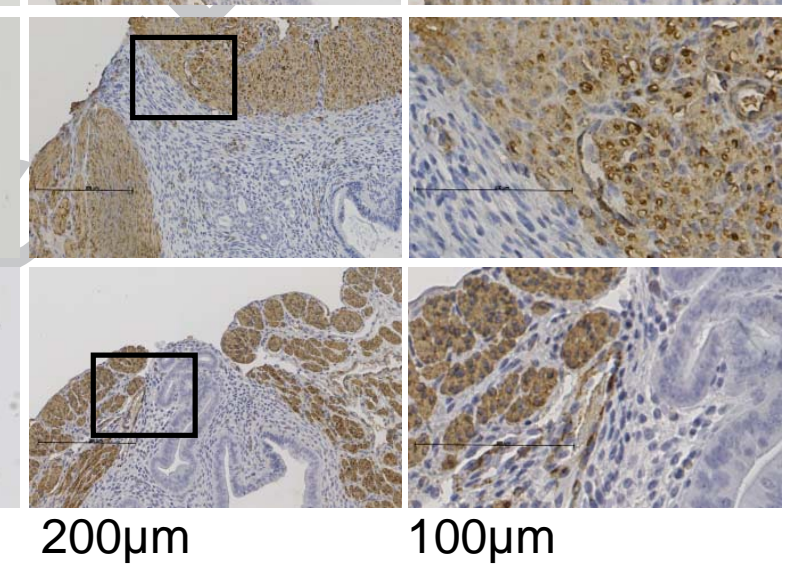

Amhr2 ${ }^{\mathrm{Cre} /+} ; A p c^{15 l o x / 15 l o x}$ 


\section{Figure 3}

\section{$P G R^{\mathrm{Cre} /+} ; A p c^{15 l o x / 15 l o x}$}

A

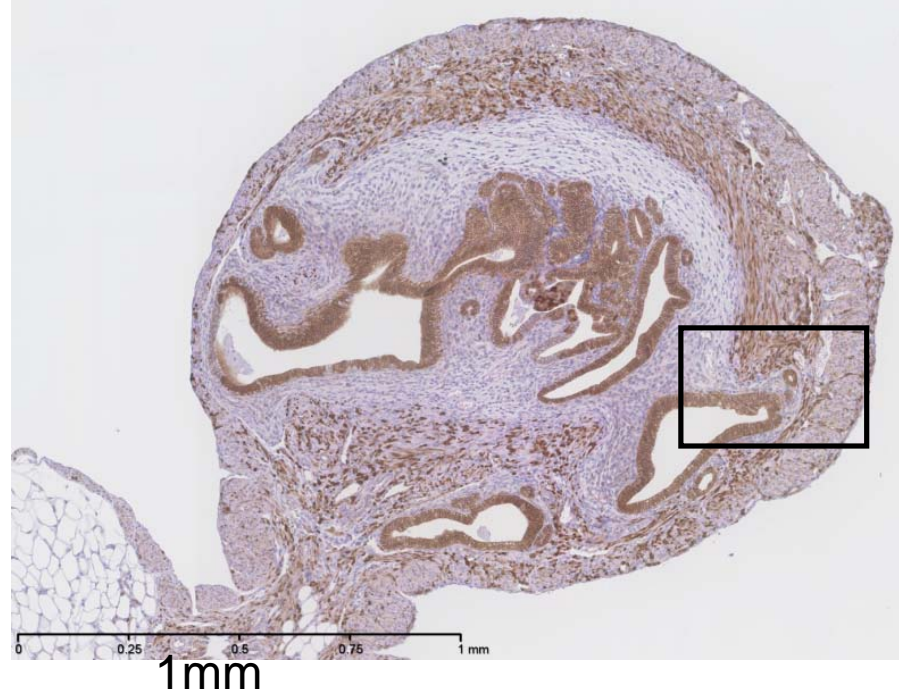

B

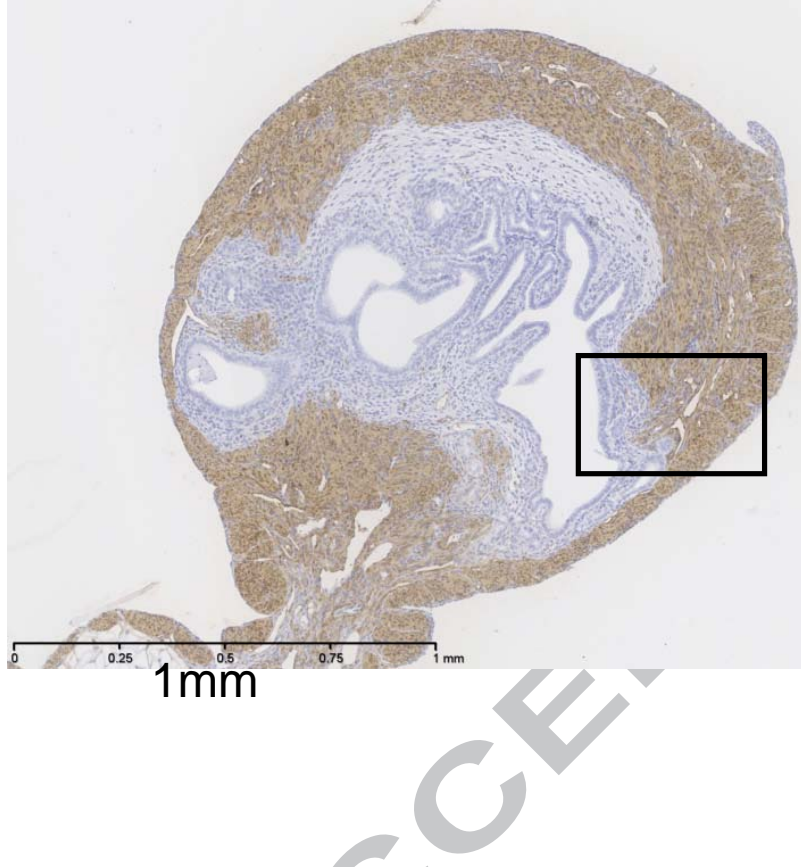

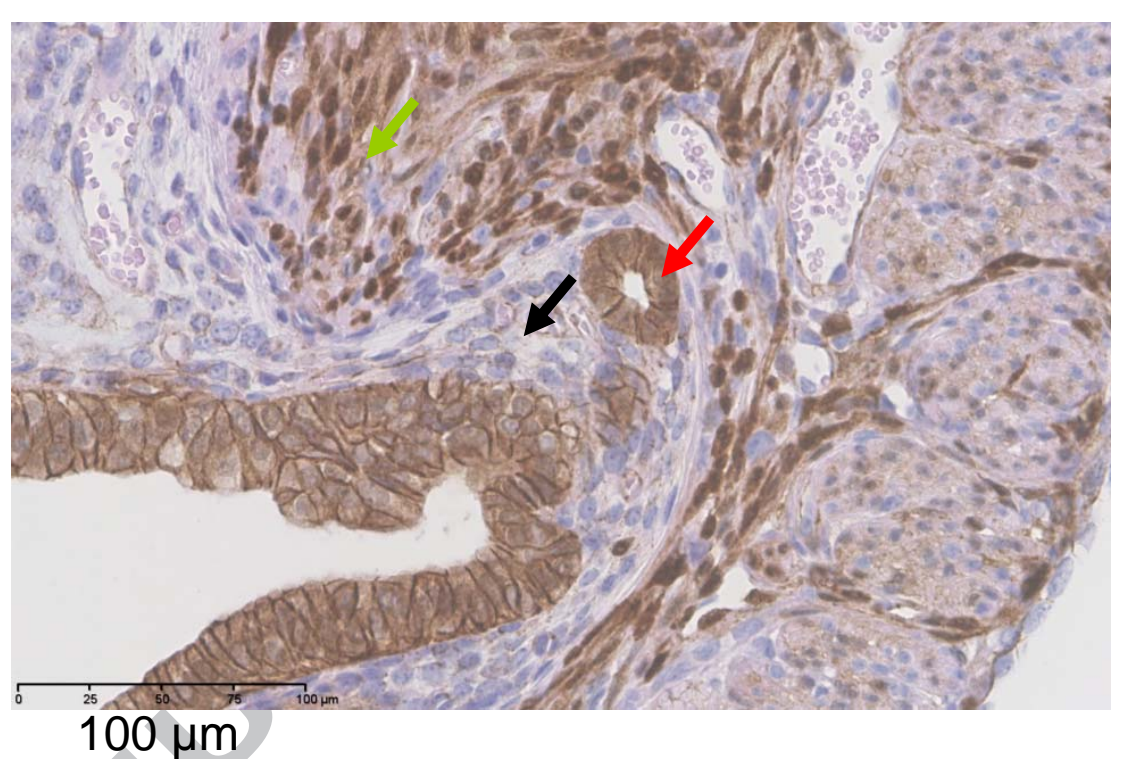

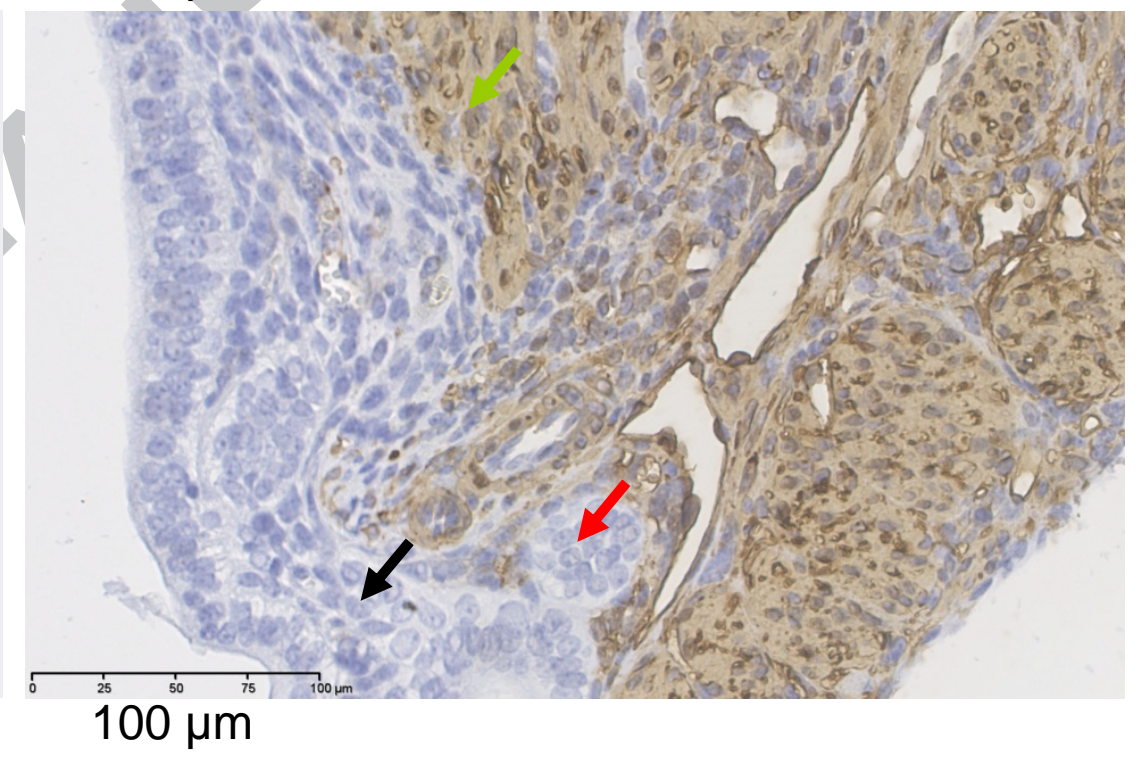


Figure 4
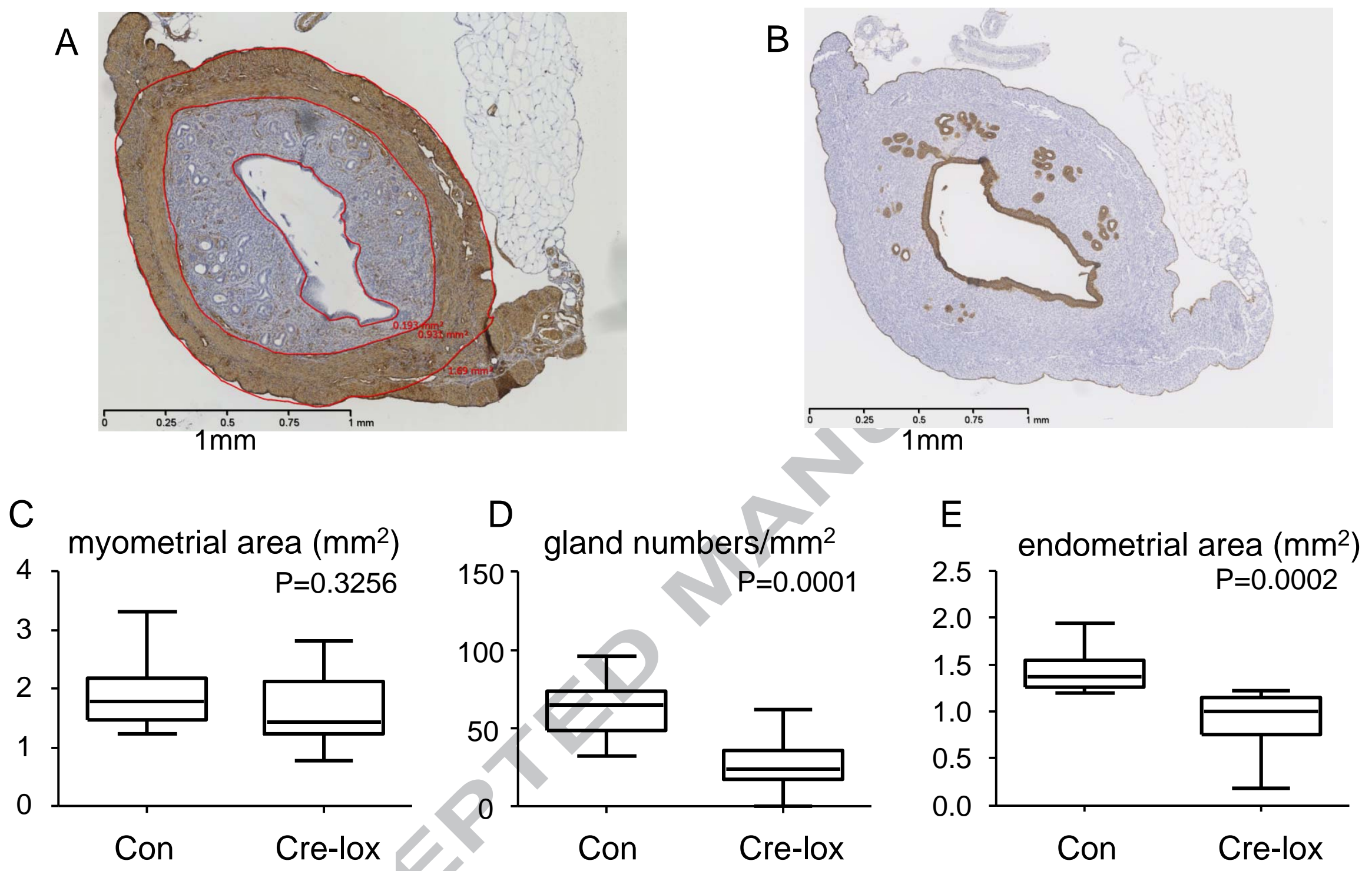


\section{Table 1: Animals investigated}

\begin{tabular}{|c|c|c|c|}
\hline Genotype & $\mathbf{N}$ & Age (weeks) & Phenotype \\
\hline Wild type & 21 & $7-31$ & normal \\
\hline$A p c^{15 l o x /+}$ & 9 & $9-33$ & normal \\
\hline$A p c^{15 l o x / 15 l o x}$ & 5 & $8-34$ & normal \\
\hline Amhr2cre/+ & 3 & $7-34$ & normal \\
\hline$A m h r 2^{\text {cre/++;Apc }}$ & 19 & $8-34$ & $\begin{array}{l}\text { Impared myometrial architecture in } \\
19 / 19 \text { animals. Discontinuation of the } \\
\text { myometrial layer in } 3 / 19 \text { animals. }\end{array}$ \\
\hline
\end{tabular}




\section{Supplementary Figure 1}

Amhr2 ${ }^{\mathrm{Cre} /+} ; A p c^{15 l o x / 15 l o x}$

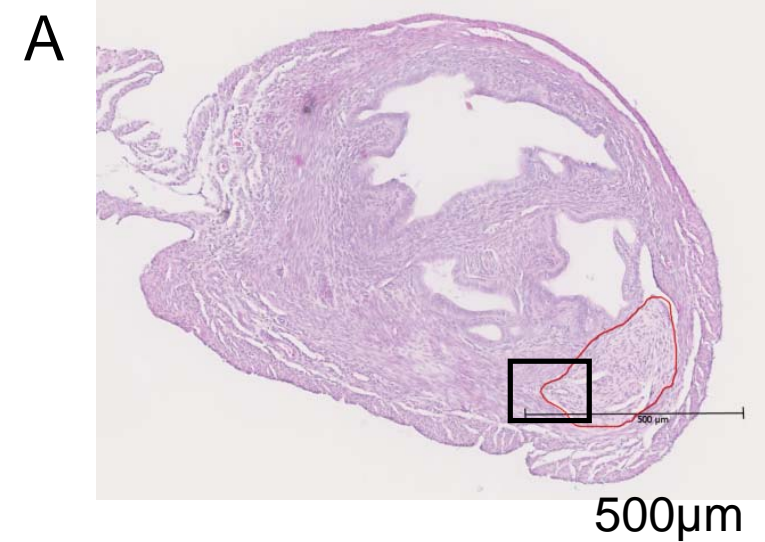

B

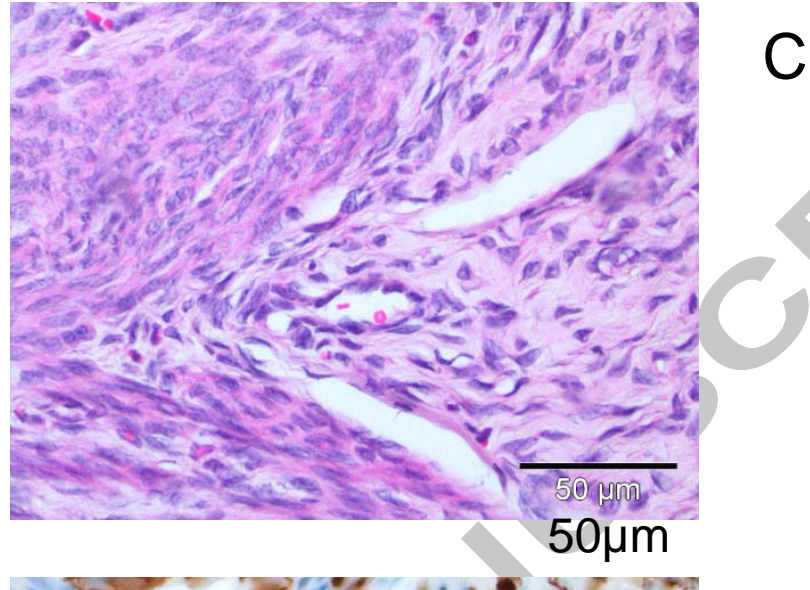

C

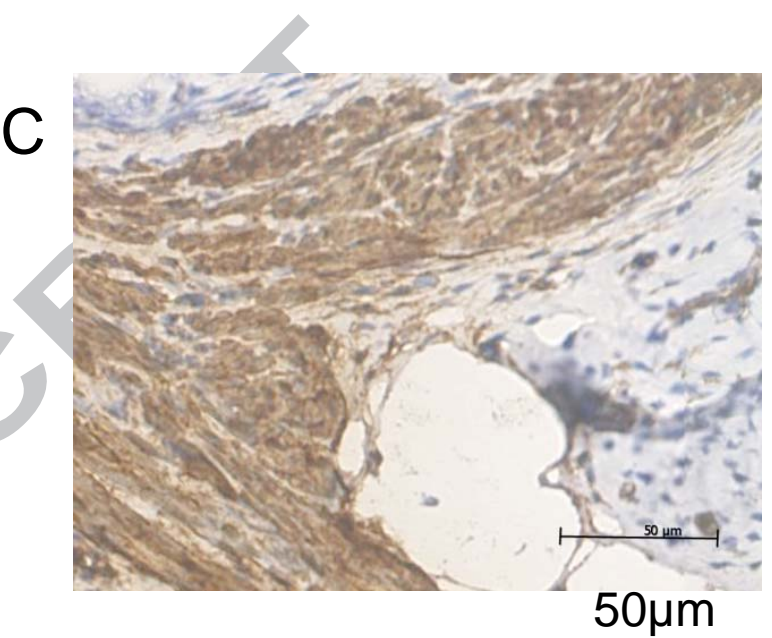

D

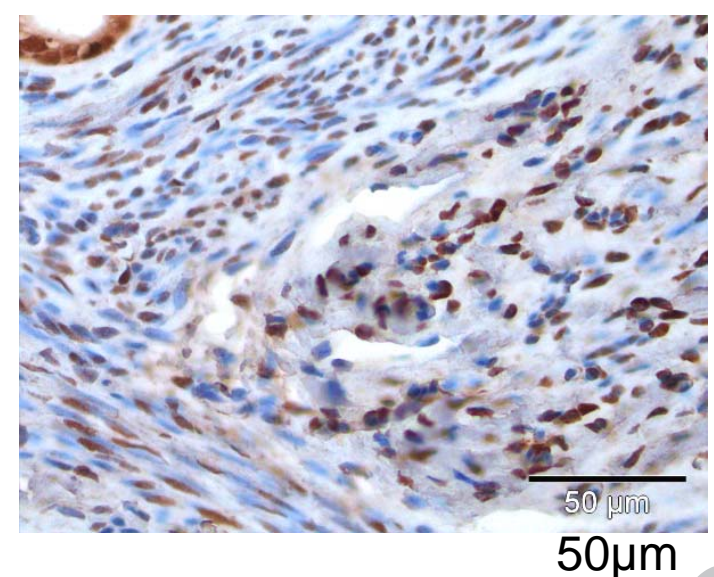

E

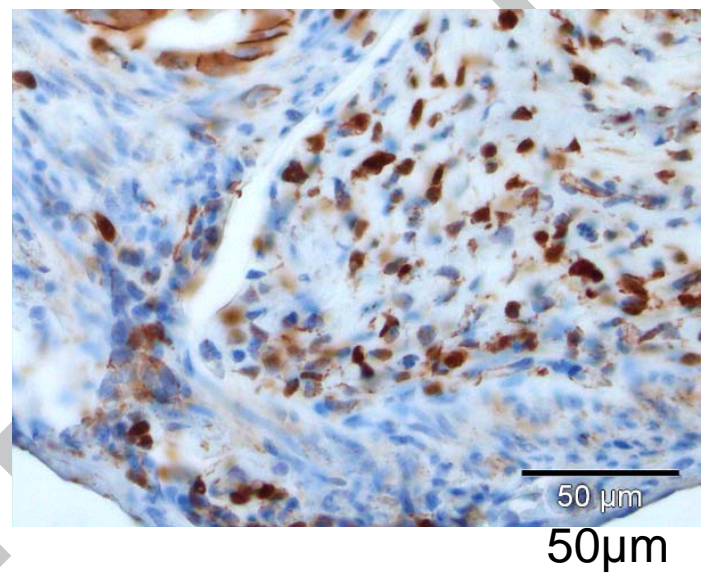


$>\mathrm{AMHR} 2^{\mathrm{Cre} /+} ; A p c^{15 l o x / 15 l o x}$ and $\mathrm{Pgr}^{\mathrm{Cre} /+} ; A p c^{15 \text { lox/15lox }}$ mouse models were used to make conditional $A p c$ knockout. > Loss of $A p c$ was induced in the adult mouse uterus.> Minor defects in endometrium. > severe defects in the uterine myometrial layers. > The WNT signaling pathway plays important roles in maintaining myometrial integrity. 